Provided for non-commercial research and education use. Not for reproduction, distribution or commercial use.

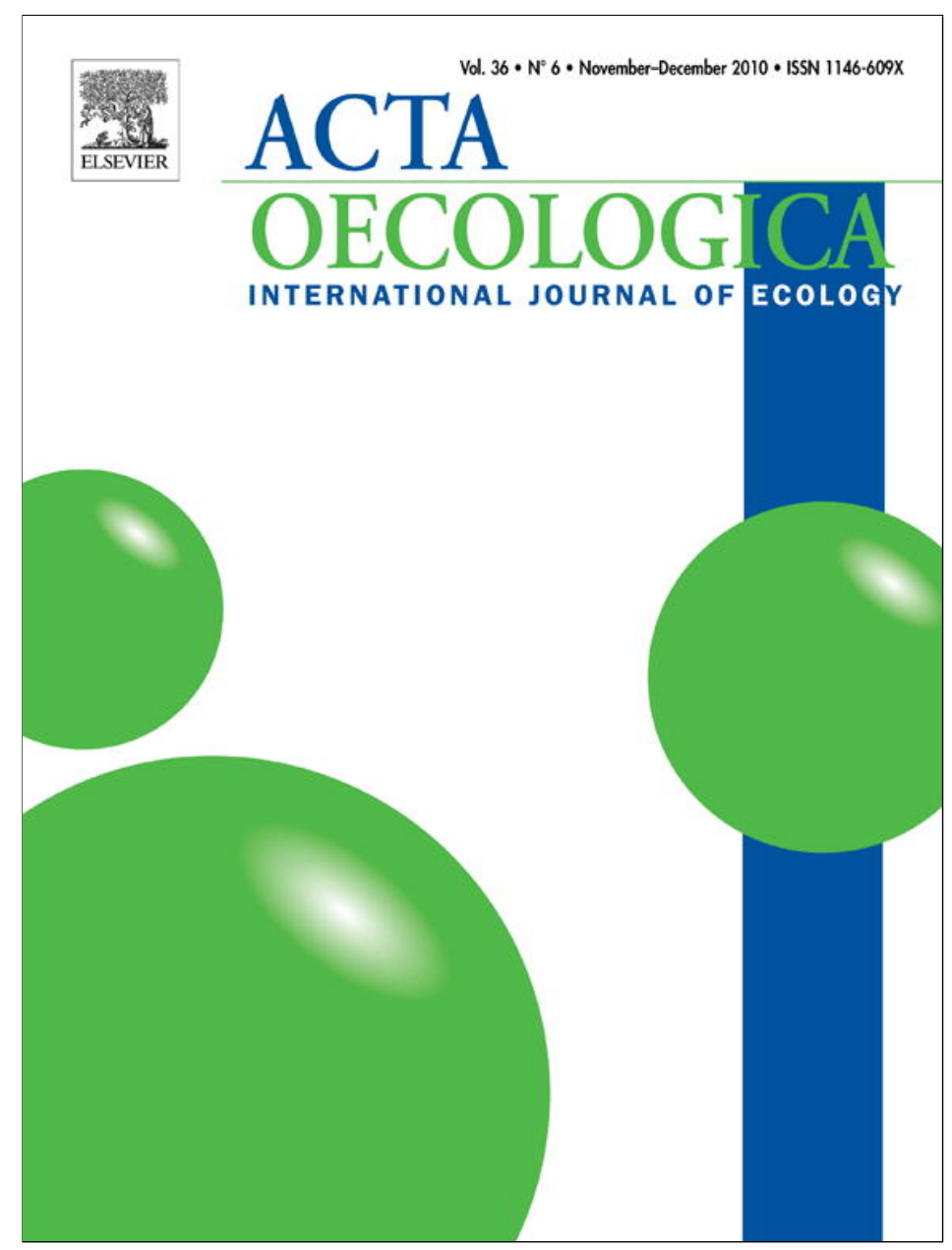

This article appeared in a journal published by Elsevier. The attached copy is furnished to the author for internal non-commercial research and education use, including for instruction at the authors institution and sharing with colleagues.

Other uses, including reproduction and distribution, or selling or licensing copies, or posting to personal, institutional or third party websites are prohibited.

In most cases authors are permitted to post their version of the article (e.g. in Word or Tex form) to their personal website or institutional repository. Authors requiring further information regarding Elsevier's archiving and manuscript policies are encouraged to visit:

http://www.elsevier.com/copyright 
Original article

\title{
Living on the edge: Space use of Eurasian red squirrels in marginal high-elevation habitat
}

\author{
Claudia Romeo, Lucas A. Wauters*, Damiano Preatoni, Guido Tosi, Adriano Martinoli \\ Dipartimento Ambiente, Salute, Sicurezza (DASS), Università degli Studi dell'Insubria, Varese, Via J.H. Dunant 3, I-21100 Varese, Italy
}

\section{A R T I C L E I N F O}

\section{Article history:}

Received 10 March 2010

Accepted 7 September 2010

Available online 2 October 2010

\section{Keywords:}

Core area

Distribution edge

Home range

Marginal habitat

Pine forests

Sciurus vulgaris

Social organization

\begin{abstract}
A B S T R A C T
In marginal habitats located at the edge of a species' range, environmental conditions are frequently extreme and individuals may be subject to different selective pressures compared to central populations. These so-called edge or marginal populations tend to have lower densities and reproductive rates than populations located in more suitable habitats, but little is known about local adaptations in spacing behavior. We studied space use and social organization in a population of Eurasian red squirrels (Sciurus vulgaris) in a high-elevation marginal habitat of dwarf mountain pine (Pinus mugo) and compared it with spacing patterns in high-quality Scots pine (Pinus sylvestris) forest at lower-elevation. Home ranges and core areas were larger in the marginal habitat. In both habitats, males used larger home ranges than females, but sex differences in core area size were significant only in the edge population. Patterns of core area overlap were similar in both habitats with intra-sexual territoriality among adult females and higher degrees of inter-sexual overlap, typical for the species throughout its range. However, low densities in the edge population resulted in higher female by males overlap in spring-summer, suggesting males increased home ranges and core areas during mating season to augment access to estrus females. Thus, in the marginal habitat, with low food abundance and low population densities, linked with extreme winter conditions, squirrels, especially males, used large home ranges. Finally, squirrels responded more strongly to variation in food availability (inverse relation between home range size and seed abundance), and even to fluctuations in density (inverse relation between core area size and density of animals of the same sex), in the marginal than in the high-quality habitat, suggesting high behavioral plasticity to respond to the ecological constraints in marginal habitats.
\end{abstract}

(c) 2010 Elsevier Masson SAS. All rights reserved.

\section{Introduction}

Limits to species' distribution can be imposed by geographical barriers or, more often, by ecological conditions that become suboptimal for their survival. Hence, in so-called 'marginal habitats' located at the border of a species' range, environmental conditions are frequently extreme and individuals are subject to different selective pressures compared to central populations (reviewed in Kawecki, 2008).

Populations living in such marginal habitats at the edge of the species' distribution are often referred to as edge populations (or marginal populations). They are usually sink-populations (reviewed in Dias, 1996) that have lower densities and reproductive rates than populations located in more suitable habitats (Vucetich and Waite, 2003; Sagarin et al., 2006), and are therefore more

\footnotetext{
* Corresponding author. Tel.: +390332 421538; fax: +390332421446.

E-mail address: l.wauters@uninsubria.it (L.A. Wauters).
}

affected by small changes in ecological factors (Gonzalez-Megias et al., 2005; Manier and Arnold, 2005). On the other hand, if these populations are enough isolated and immigration and gene flow are reduced, they can develop local adaptations to such extreme habitats, diverging from central, source-populations (Garcia-Ramos and Kirkpatrick, 1997; Kirkpatrick and Barton, 1997; Case and Taper, 2000; reviewed in Kawecki, 2008). For both these reasons, studying marginal populations can be very interesting to understand contraction and expansion mechanisms of geographic ranges and, in general, species' response to climate and habitat alterations (Thomas et al., 2001; Wiens and Graham, 2005; Parmesan, 2006).

Several studies explored variability in vertebrate's population dynamics along altitudinal or latitudinal gradients and compared vital rates of central and marginal populations (e.g. Spencer and Steinhoff, 1968; Millar and Innes, 1985; Zammuto and Millar, 1985; Ferguson and McLoughlin, 2000; Badyaev and Ghalambor, 2001; García and Arroyo, 2001), but few have focused on behavioral adaptations in edge populations involving space or habitat use 
(Smith, 1974 on pikas; Mehlman, 1989 on primates; Sound and Veith, 2000 on western green lizards; Caudron et al., 2001 on grey seals; Sunde et al., 2001 on Tawny owls).

The aim of this study was to investigate space use by Eurasian red squirrel (Sciurus vulgaris) in a high-elevation forest with low resource abundance (Rodrigues et al., 2010) in order to understand if living on the edge can affect species' spatial behavior. Eurasian red squirrel is a widespread arboreal mammal that exploits a wide variety of forest habitats along a wide geographical ranges (Lurz et al., 2005). Species' demography, social behavior and space use are strongly affected by its main food resource, tree seeds, whose availability is highly variable in seasons and years (Wauters and Dhondt, 1992; Wauters and Lens, 1995; Lurz et al., 2000; Wauters et al., 2004; Boutin et al., 2006; Zong et al., 2010). We collected radio-tracking data and estimated food availability in two populations living in different conifer forests. One is an edge population located at the upper elevation limit of squirrel's distribution in a dwarf mountain pine (Pinus mugo Turra) wood with extreme weather conditions (Rodrigues et al., 2010) hereinafter called mountain pine forest; the second one is a high density population (Wauters et al., 2008) in a lower-elevation, montane Scots pine (Pinus sylvestris) forest (hereinafter called Scots pine forest).

In studies carried out in single sites, spatio-temporal variation in squirrel home ranges is negatively correlated with the availability of tree seeds (e.g. Lurz et al., 2000; Wauters et al., 2005; Di Pierro et al., 2008). Therefore, we predict that in mountain pine forest, where food availability is lower, squirrels have larger home ranges and core areas than in Scots pine forest. We explore the partial effects of food availability and (intra-sexual) squirrel densities on home range (core area) size in both habitats.

\section{Materials and methods}

\subsection{Study area}

We studied red squirrels and counted cones at two study sites in the central Italian Alps, Lombardy, N. Italy. Distance between the two areas is $11 \mathrm{~km}$. Cancano (CAN the mountain pine forest, $46^{\circ} 33^{\prime} \mathrm{N}, 10^{\circ} 15^{\prime} \mathrm{E}$, elevation from $1940 \mathrm{~m}$ to $1970 \mathrm{~m}$ a.s.l.) is located in the Stelvio National Park in a high-elevation valley. The study site ( 60 ha, mean tree density $\pm S D=2888 \pm 1128$ trees ha $^{-1}$ ) is almost entirely composed of a homogeneous dwarf mountain pine (P. mugo Turra) subalpine woodland. P. mugo seeds, representing the major and almost unique food resource for squirrels, mature inside small cones in September and are dispersed by wind the next spring. Mean energy content per cone is $5.9 \mathrm{~kJ}$ (our unpubl. data).

The second study site, Oga (OGA, the Scots pine forest, $46^{\circ} 28^{\prime} \mathrm{N}, 10^{\circ} 22^{\prime}$ E, elevation from $1280 \mathrm{~m}$ to $1450 \mathrm{~m}$ a.s.l.), is part of a mature mixed montane conifer forest ( 47 ha, mean tree density $\pm \mathrm{SD}=765 \pm 251$ trees ha $\left.{ }^{-1}\right)$, dominated by Scots pine (P. sylvestris, $88.7 \%$ tree cover) with some Norway spruce (Picea abies, 8.8\%) and larch (Larix decidua, 2.5\%). Both Scots pine and larch seed-dispersal starts in late spring, after snow melting, while Norway spruce cones ripen in autumn and seed fall occurs from winter until late spring. Mean energy content per cone is $7.5 \mathrm{~kJ}$ for Scots pine, $51.1 \mathrm{~kJ}$ for Norway spruce and $9.4 \mathrm{~kJ}$ for larch (Salmaso et al., 2009).

The two sites are characterized by a continental pluviometric regime typical of the central alpine region, with low to moderate annual precipitation (2003-2009: mean $\pm S D=564 \pm 226 \mathrm{~mm}$ in Cancano, $809 \pm 233 \mathrm{~mm}$ in Oga) occurring mostly in summer. The mountain pine forest has a high-elevation climate with mean annual temperature below $3^{\circ} \mathrm{C}\left(2003-2009\right.$ : mean $\left.\pm \mathrm{SD}=2.6 \pm 0.5^{\circ} \mathrm{C}\right)$ and long, cold winters (mean monthly temperatures below $0{ }^{\circ} \mathrm{C}$ up to 6 months a year). Duration and depth of permanent snow cover vary annually, but between 30 and $150 \mathrm{~cm}$ of snow tend to cover the study site between early November and late April-May (Cancano meteorological station, $1948 \mathrm{~m}$ a.s.l., A.R.P.A. Lombardy). Due to its lower altitude, the Scots pine forest has a warmer climate with higher mean annual temperatures (2003-2009: mean $\pm \mathrm{SD}=8.1 \pm 0.6{ }^{\circ} \mathrm{C}$ ) and mean monthly temperatures below $0^{\circ}$ for no more than 3 months a year (Bormio meteorological station, $1230 \mathrm{~m}$ a.s.l., A.R.P.A. Lombardy). In most years, snow covers the ground from December till late March.

\subsection{Estimating food availability}

Tree-seed abundance of conifers was estimated as described elsewhere (Salmaso et al., 2009). Briefly, we determined woodland

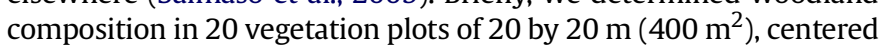
on the trapping stations. In each plot, the number of trees was counted, and the diameter at breast height $(\mathrm{DBH}$ in $\mathrm{cm}$ ) of two randomly chosen mature trees, hereinafter called "sample trees", was measured. Each year (between 25 July and 5 August), the new (current year) maturing cones were counted in the canopy of all sample trees from a fixed position using $10 \times 40$ binoculars. Average numbers of seeds per cone and cone-energy value $\left(\mathrm{kJ} \mathrm{cone}^{-1}\right)$ were determined as in Salmaso et al. (2009). The mean energy production, over all plots, was our estimate of annual seed production (Salmaso et al., 2009). Overall seed-crop size (mean \pm SE) was $276 \pm 202 \mathrm{MJ} \mathrm{ha}^{-1}, 404 \pm 220 \mathrm{MJ} \mathrm{ha}^{-1}$, and $767 \pm 274 \mathrm{MJ} \mathrm{ha}^{-1}$, respectively in 2006, 2007 and 2008 in the mountain pine forest (Rodrigues et al., 2010), and $1732 \pm 419 \mathrm{MJ} \mathrm{ha}^{-1}, 391 \pm 82 \mathrm{MJ} \mathrm{ha}^{-1}$, $557 \pm 85 \mathrm{MJ} \mathrm{ha}^{-1}, 735 \pm 153 \mathrm{MJ} \mathrm{ha}^{-1}$ and $525 \pm 85 \mathrm{MJ} \mathrm{ha}^{-1}$ in 1999, 2000, 2001, 2002 and 2003, respectively, in the Scots pine forest (Wauters et al., 2008).

In a second step, we estimated food availability in each squirrel's home range (home range quality) as the mean food abundance $\left(\mathrm{kJ} \mathrm{ha}^{-1}\right)$ of all vegetation plots within the $95 \%$ home range area using the kernel estimator (KDE, see below). Seeds produced in summer-autumn of year t were considered available for squirrels during the following 'squirrel year' (see Wauters and Lens, 1995), i.e. from August of year $t$ to July of year $t+1$.

\subsection{Trapping and radio-tracking}

Trapping was carried out in four to five periods per year, from April 2006 to April 2009 in CAN, and in three periods per year (April, June-July, October) from April 2000 to April 2006 in OGA. A trapping session involved the use of 31 (mountain pine forest) or 25 (Scots pine forest) ground-placed Tomahawk "squirrel" traps (models 201 and 202, Tomahawk Live Trap, WI, USA). Traps were placed on a grid, with distances of 100-150 $\mathrm{m}$ between them and average density of $0.6-0.7$ traps $\mathrm{ha}^{-1}$. Trapping and handling were carried out as in Wauters et al. (2008). Each trapped squirrel was individually marked using numbered metal ear-tags (type 1003S, 10 by $2 \mathrm{~mm}$, National Band and Tag, Newport, KY, USA) and weighed to the nearest $5 \mathrm{~g}$ using a spring-balance (Pesola AG, Baar, Switzerland). Sex, age and reproductive condition (active $=$ reproducing, or not active $=$ nonreproducing) were recorded following Wauters and Dhondt (1989, 1995). Trapping and handling squirrels complied with the current laws on animal research in Italy and were carried out under permission of the Region of Lombardy.

The minimum number of animals known to be alive from capture-mark-recapture, radio-tracking and observations, during each trapping period was used to estimate population size and density of each sex. Previous studies on a wide range of tree squirrel populations have shown that these estimates are consistently close to true squirrel densities (e.g. Kenward et al., 1998; Wauters et al., 2004, 2008; Boutin et al., 2006). 
In Cancano, 11 different adult squirrels were radio-collared (type M1640 radio-collar, ATS Inc., Isanti, MN, USA) between April 2006 and October 2008. We monitored 2 males and 1 female in 2006, 3 males and 4 females in 2007, 3 males and 2 females in 2008. Two females and 1 male were monitored in more than one year, for a total of 24 range estimates. Within each season, between 60 and $100 \%$ of resident adults were radio-tracked (Rodrigues et al., 2010). In Oga, in April-June 2000 and between April and September 2003, we radio-collared 19 different adult red squirrels ( 6 males, 4 females in 2000; 6 males, 6 females in 2003, three of which, two males and one female, already monitored in 2000) with adjustable necklace transmitters (PD-2C transmitters, Holohil Systems Ltd., Carp, Ontario, Canada or TW-4 transmitters, Biotrack Ltd., Wareham, Dorset, UK). Total sample size was 28 range estimates. Within each season, between 75 and $77 \%$ of resident adults were radio-tracked (our unpubl. data).

We estimated locations (hereinafter called fixes) to the nearest 10 by $10 \mathrm{~m}$ by homing-in to the radio-signal (Wauters and Dhondt, 1992; Wauters et al., 2001) using a Wildlife TRX-2000S receiver with a directional three-element yagi antenna (150-152 MHz, Wildlife Materials Inc., Murphysboro, IL 62966, USA) and a handheld GPS (Garmin GPS-II plus). Data were converted to the Italian coordinate reference system (Gauss-Boaga, West zone, ED50 datum). We monitored all squirrels for six to eight months (April/ May-October/November) taking one or two fixes per day (one during morning activity bout, the second in the afternoon when the animal was in or had left a nest, Wauters, 2000). The interval between consecutive radio-tracking days was irregular. This sampling interval avoided autocorrelation in location data (e.g. Swihart and Slade, 1985). At each fix squirrel activity ( $1=$ active, $2=$ in a nest) and tree species used (or ground) were recorded. Per year, we estimated home ranges at a seasonal basis: springsummer (April-July) and autumn (September-November). However, in 2006 (mountain pine forest) a single spring-summer range (May-September) was estimated. In each season, the location of each drey (nest site) was only used once in data analyses to avoid clumping of fixes caused by repeated use of single dreys. Within each radio-tracking period (season in year), we collected between 15 and 117 fixes per animal ( $n=52$ ranges, mean $\pm \mathrm{SD}=38 \pm 18$ ), which was sufficient to describe adequately squirrels' home ranges (e.g. Lurz et al., 2000; Wauters et al., 2001).

\subsection{Home range and core area estimators}

We analyzed all data on home range size, core area size, and overlap of home ranges with the RANGES 6 program (Kenward et al., 2003).

Based on earlier work (Wauters et al., 2005, 2007) we calculated home range size using the $100 \%$ minimum convex polygon (100\% MCP) and the 95\% fixed kernel probability density estimator with reference smoothing factor (95\% KDE with $h_{\text {ref }}$ ). Method used to calculate bandwidth $h$ strongly affects KDE home range estimates (e.g. Seaman and Powell, 1996; Hemson et al., 2005). To avoid overestimation with KDE we used the adjusted $h\left(h_{a d j}=0.75 \times h_{\text {ref }}\right.$ in our case) proposed as recalculated bandwidth to produce more reliable home range and core area estimates (Wauters et al., 2007). The 95\% KDE contours eliminated outliers, thus excluding the sally zones (Di Pierro et al., 2008) from the estimated home range size. Core area size was estimated using the $85 \%$ minimum convex polygon (85\% MCP) and 85\% KDE (see also Lurz et al., 2000; Wauters et al., 2005). The two home range estimators and two core area estimators were strongly correlated (all $r>0.92, P<0.0001$ ). Therefore, we only used $95 \% \mathrm{KDE}$ and $85 \% \mathrm{MCP}$ in our models exploring variation in home range and core area size. Our range size estimates were not affected by the number of fixes used to calculate range size (for all estimators $n=52, r<0.22, P>0.10$ ).

Core area overlap was calculated using the $85 \%$ MCP. Within each season and year, core area overlap was calculated by summing the percentages of overlap of a squirrel's core area with the core area of all other squirrels of either sex (Wauters and Dhondt, 1992).

\subsection{Statistical analyses}

Individual variation in home range and core area size was investigated using General Linear Mixed Models (GLMM, Proc mixed, SAS 1999) with individual added as a repeated measure to account for pseudoreplication (Verbeke and Molenberghs, 2000). In each analysis we started from a saturated model with the dependent variable log-transformed home range size (ln 95\% KDE) or logtransformed core area size ( $\ln 85 \% \mathrm{MCP})$, and study site, sex, season, density same sex, density other sex (spring or autumn density in a given year), log-transformed home range quality, and all 2-way interactions with site, sex, season and home range quality. Data on home range (core area) size and home range quality met assumptions of homogeneity of variances after log-transformation. The distribution of the residuals was explored using the Shapiro-Wilk statistic and did not deviate from normality. In squirrels, variation in home range quality explains most of the between year variation in home range size (e.g. Wauters and Dhondt, 1992; Lurz et al., 2000; Di Pierro et al., 2008), therefore year was not added as fixed effect. We compared three different correlation structures of the residual correlation matrix (SIMPLE, corresponding to the absence of an effect of repeated measures on an individual, CS = compound symmetry, assuming a correlation between two measures on the same individual that does not vary over time, $\operatorname{AR}(1)=$ first order autoregression assuming that the correlation between two measures on the same individual is a function of the time-interval between them, Verbeke and Molenberghs, 2000). Models with simple correlation structure had the smaller values of Schwarz's Bayesian Information Criterion, indicating better fit (Verbeke and Molenberghs, 2000). After selecting the simple correlation structure, we continued testing fixed effects and performed model selection using a backward procedure. Degrees of freedom and standard errors of $F$ - and $t$-tests were obtained using KenwardRogers method (Verbeke and Molenberghs, 2000). Interpretation of final models were based on differences of least square means (DLSM).

Data of body mass and reproductive condition were not available for all animals in each study period, therefore we tested their effects on home range and core area size for a subset of data. Since reproductive condition differs between the sexes (males: not active with abdominal testes, or active with scrotal testes; females: not active, anoestus and not lactating, or active when pregnant or lactating), we used separate General Linear Mixed Models for males and females, with log-transformed home range or core area size as dependent variable and body mass and reproductive condition as explanatory variables, with individual added as a repeated measure.

An important parameter of spacing behavior in squirrels is the pattern of core area overlap (Wauters and Dhondt, 1992). Core area overlap data met assumptions of homoscedasticity. We used \% core area overlap with animals of either sex as dependent variable in our models testing for variation in core area overlap. We tested the fixed effects of sex, sex of the overlapping animal, study site and season, and a sex by overlapping sex interaction (e.g. Wauters et al., 2005). The distribution of the residuals did not deviate from normality. The interaction term allowed us to explore whether overlap differed among the sexes, in other words whether there were differences in overlap for male by males, male by females, female by males and female by other females. Adding 3-way 
interactions of sex $\times$ overlapping sex with site and season allowed us to investigate whether patterns of intra- and/or inter-sexual overlap differed among sites or seasons. Individual was included as a repeated measure and the modeling procedures were identical to models of home ranges size. Using square-root proportion overlap gave similar results (data not shown).

All tests of significance are two-tailed and the significance level was set at 0.05 . Unless otherwise indicated values are presented in the text as mean $\pm \mathrm{SD}$.

\section{Results}

\subsection{Home range and core area size}

On average, home range quality was larger in Scots pine than in mountain pine forest (Scots pine forest $n=28,912 \pm 781 \mathrm{MJ} \mathrm{ha}^{-1}$; mountain pine forest $n=24,477 \pm 220 \mathrm{MJ} \mathrm{ha}^{-1} F_{1,50}=6.95$, $P=0.011$ ).

Squirrels in mountain pine forest had larger home ranges than in Scots pine forest and, in both sites, males used larger home ranges than females (Tables 1 and 2). The partial effect of season was not significant (Table 2). A site by home range quality interaction indicated that the relation between home range quality and home range size differed between sites (Table 2): therefore we tested the effect of sex, season, ln home range quality, density same sex and density other sex on home range size for mountain pine and Scots pine forest separately.

In mountain pine forest, males had larger home ranges than females (Sex effect $F_{1,21}=18.4, P=0.0003$, Table 1 ). HRQ was negatively related with home range size, indicating that squirrels used smaller ranges when tree-seed abundance inside the home range was high ( $\ln \mathrm{HRQ} F_{1,21}=8.33, P=0.009, b=-0.70 \pm 0.24$, Fig. 1). In Scots pine forest, there was no effect of HRQ (ln HRQ $F_{1}$, $25=1.07, P=0.31$, Fig. 1 ). Males tended to use larger ranges than females, although the sex effect was not significant $\left(F_{1,26}=3.63\right.$, $P=0.068$, Table 1 ). There was no effect of season, male or female density in any of the two sites (all $P>0.10$ ).

Male squirrels also had larger core areas than females and squirrels used larger core areas in mountain pine than in Scots pine forest (effect of site as single factor on core area size $F_{1,50}=24.9$, $P<0.0001$ ), but the partial effect of site in the GLMM was not significant (Tables 1 and 2). Although core areas tended to be larger in spring-summer than in autumn, the season effect was not significant (Tables 1 and 2). Squirrels reduced their core areas when
Table 2

General Linear Mixed Models exploring variables and factors explaining variation in home range size (ln 95\% KDE estimator) and core area size (ln 85\% MCP estimator) among red squirrels radio-tracked in two study sites in the Central Italian Alps. A stepwise backward selection removed non-significant variables and factors. $\mathrm{HRQ}=$ home range quality.

\begin{tabular}{lll}
\hline Dependent variable & Home range size & Core area size \\
\hline \multicolumn{2}{l}{ Variables and factors removed } & \\
Site $\times$ season & $F_{1,39}=0.35 ; P=0.56$ & $F_{1,39}=0.22 ; P=0.64$ \\
Site $\times$ sex & $F_{1,40}=0.65 ; P=0.43$ & $F_{1,40}=0.40 ; P=0.53$ \\
Sex $\times$ season & $F_{1,41}=0.93 ; P=0.34$ & $F_{1,41}=0.93 ; P=0.34$ \\
Density other sex & $F_{1,42}=0.03 ; P=0.87$ & $F_{1,42}=0.01 ; P=0.97$ \\
In HRQ $\times$ season & $F_{1,44}=2.69 ; P=0.11$ & $F_{1,43}=1.87 ; P=0.18$ \\
In HRQ $\times$ sex & $F_{1,43}=3.89 ; P=0.06$ & $F_{1,44}=2.87 ; P=0.10$ \\
Season & $F_{1,45}=1.63 ; P=0.21$ & $F_{1,45}=3.20 ; P=0.081$ \\
Density same sex & $F_{1,46}=2.59 ; P=0.11$ & \\
In HRQ $\times$ site & & $F_{1,46}=1.95 ; P=0.17$ \\
In HRQ & & \\
Selected model & & \\
Sex & $F_{1,47}=16.2 ; P=0.0002$ & $F_{1,48}=24.7 ; P<0.0001$ \\
Site & $F_{1,47}=8.26 ; P=0.006$ & $F_{1,48}=0.43 ; P=0.51$ \\
In HRQ & $F_{1,47}=2.61 ; P=0.11$ & \\
In HRQ $\times$ site & $F_{1,47}=7.07 ; P=0.011$ & \\
Density same sex & & $F_{1,48}=11.2 ; P=0.0016$ \\
\hline
\end{tabular}

density of animals of the same sex increased (Table 2, $b=-9.63 \pm 2.87$, Fig. 2).

We also explored variation in core area size for the two sites separately. In mountain pine forest, males had larger core areas than females ( $\operatorname{sex}$ effect $F_{1,21}=30.5, P<0.0001$ ) and core area size decreased with increasing density of animals of the same sex $\left(F_{1,21}=11.1, P=0.003, b=-9.6 \pm 2.9\right.$, Fig. 2$)$, while the partial effect of HRQ was negative, but not significant (ln HRQ $F_{1,20}=2.87$, $P=0.11, b=-0.43 \pm 0.25)$. In contrast, in Scots pine forest there was no relationship with any of the variables or with season (all $P>0.10$ ) and also the sex effect was not significant $\left(F_{1,26}=1.74, P=0.20\right)$.

For either males or females, there was no relationship of body mass and reproductive condition with home range or core area size (all $P>0.40)$.

\subsection{Core area overlap}

Percentage of core area overlap ranged between 0 and $174 \%$ $(n=104)$. There was no interaction with study site and no effect of study site on degree of overlap (sex by overlapping sex by site $F_{3}$, $62=1.80, P=0.16$; site effect $F_{1,46}=0.48, P=0.49$ ), hence patterns of overlap were similar in both sites (Table 3 ).

Table 1

Home range size (100\% MCP and 95\% KDE estimators) and core area size (85\% MCP and 85\% KDE estimators, see methods) of Eurasian red squirrels in two study sites in the Central Italian Alps. Range size (mean \pm SD, in ha) per study site and sex and per site, sex and season.

\begin{tabular}{|c|c|c|c|c|c|}
\hline \multirow[t]{2}{*}{ Site } & \multirow[t]{2}{*}{ Sex } & \multicolumn{2}{|c|}{ Home range size (ha) } & \multicolumn{2}{|c|}{ Core area size (ha) } \\
\hline & & $100 \% \mathrm{MCP}$ & $95 \% \mathrm{KDE}$ & $85 \% \mathrm{MCP}$ & $85 \% \mathrm{KDE}$ \\
\hline \multirow[t]{2}{*}{ CAN } & $\mathrm{M}(n=13)$ & $27.17 \pm 17.38$ & $23.13 \pm 12.73$ & $15.29 \pm 7.59$ & $17.15 \pm 10.04$ \\
\hline & $\mathrm{F}(n=11)$ & $10.78 \pm 4.47$ & $9.68 \pm 4.47$ & $6.01 \pm 2.50$ & $6.97 \pm 3.20$ \\
\hline \multirow[t]{2}{*}{ OGA } & $\mathrm{M}(n=15)$ & $9.58 \pm 5.81$ & $8.36 \pm 5.97$ & $5.20 \pm 3.64$ & $6.09 \pm 4.01$ \\
\hline & $\mathrm{F}(n=13)$ & $5.45 \pm 3.00$ & $4.75 \pm 2.32$ & $3.21 \pm 1.45$ & $3.64 \pm 1.86$ \\
\hline \multicolumn{6}{|l|}{ CAN } \\
\hline \multirow[t]{2}{*}{ Spr-sum } & $\mathrm{M}(n=7)$ & $38.15 \pm 16.36$ & $30.88 \pm 11.48$ & $20.25 \pm 5.68$ & $25.59 \pm 9.17$ \\
\hline & $\mathrm{F}(n=6)$ & $12.15 \pm 4.46$ & $10.71 \pm 5.39$ & $6.86 \pm 2.66$ & $7.89 \pm 3.79$ \\
\hline \multirow[t]{2}{*}{ Autumn } & $\mathrm{M}(n=6)$ & $14.35 \pm 6.16$ & $14.08 \pm 6.97$ & $9.51 \pm 5.01$ & $9.64 \pm 3.95$ \\
\hline & $\mathrm{F}(n=5)$ & $9.13 \pm 4.34$ & $8.44 \pm 3.18$ & $5.00 \pm 2.12$ & $5.87 \pm 2.22$ \\
\hline \multicolumn{6}{|l|}{ OGA } \\
\hline \multirow[t]{2}{*}{ Spr-sum } & $\mathrm{M}(n=10)$ & $8.92 \pm 5.06$ & $7.12 \pm 3.73$ & $4.60 \pm 2.34$ & $5.21 \pm 2.84$ \\
\hline & $\mathrm{F}(n=7)$ & $7.00 \pm 3.37$ & $5.84 \pm 2.70$ & $3.84 \pm 1.76$ & $4.55 \pm 2.16$ \\
\hline \multirow[t]{2}{*}{ Autumn } & $\mathrm{M}(n=5)$ & $10.89 \pm 7.55$ & $10.84 \pm 9.03$ & $6.40 \pm 5.60$ & $7.85 \pm 5.68$ \\
\hline & $\mathrm{F}(n=6)$ & $3.64 \pm 0.82$ & $3.48 \pm 0.74$ & $2.48 \pm 0.41$ & $2.57 \pm 0.41$ \\
\hline
\end{tabular}




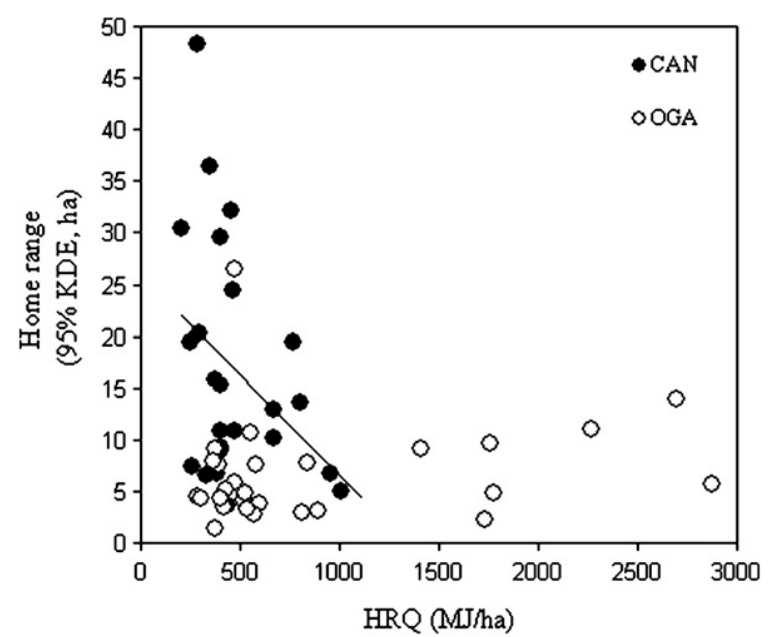

Fig. 1. Relationship between food abundance within the home range (HRQ) and home range size of red squirrels in two pine forests in the Italian Alps.

In general, percentage overlap of a squirrel's core area was higher with the core areas of males than with females (effect of overlapping sex $F_{1,48}=14.5, P=0.0004$ ), but patterns of core area overlap also differed between males and females (sex by overlapping sex interaction $F_{1,48}=12.0, P=0.001$ ). On average, males were overlapped to a similar degree by other males and by females (mean \pm SE: male by males $29 \pm 6 \%$, male by females $24 \pm 6 \%$, DLSM $P=0.88$ ), but females were more strongly overlapped by males than by other females (mean \pm SE: female by males $62 \pm 11 \%$, female by females $9.8 \pm 2.8 \%$, DLSM $P<0.0001$ ). As far as intersexual overlap was concerned, females were overlapped more strongly by males than males by females (DLSM $P=0.005$ ). Although the degree of intra-sexual overlap was on average $19 \%$ higher among males than among females, it did not differ significantly between the sexes (DLSM $P=0.19$ ).

Overlap among squirrel core areas tended to be higher in spring-summer than in autumn (Table $3, F_{1,48}=3.49, P=0.068$ ), while the season by sex by overlapping sex interaction was not significant $\left(F_{3}, 65=2.27, P=0.09\right)$. Exploring the pairwise comparisons (overlap in spring-summer against autumn for each

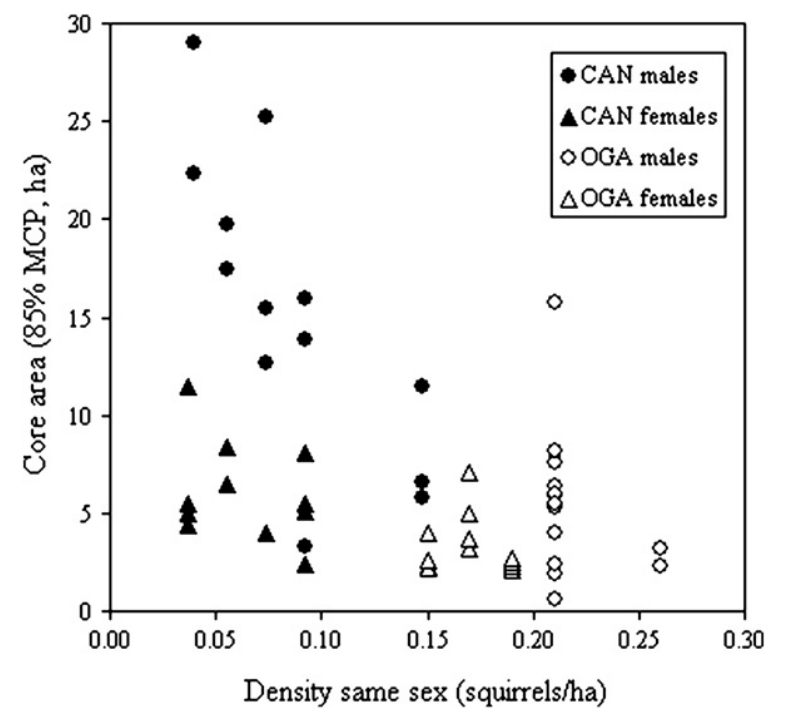

Fig. 2. Relationship between density of animals of the same sex and core area size of male and female red squirrels in two pine forests in the Italian Alps. sex by overlapping sex combination), the degree of overlap of a female's core area by males was higher in spring-summer than in autumn (DLSM $P=0.004$ ). In contrast, there was no effect of season on the degree of male by males, female by males or female by females overlap (DLSM all $P>0.2$ ).

\section{Discussion}

In Eurasian red squirrel, home range and core area size is usually dependent on several factors, such as animal density, season and habitat quality: hence, space use in this species can be complex and variable in space and time (Wauters and Dhondt, 1992, 1998; Lurz et al., 2000; Wauters et al., 2001, 2005). In particular, an inverse relationship between food abundance and home range size is commonly observed not only in Eurasian red squirrel (Wauters and Dhondt, 1992; Lurz et al., 2000; Wauters et al., 2005; Di Pierro et al., 2008), but in many vertebrate populations in temperate regions (e.g. Simon, 1975; Hixon, 1980; Taitt and Krebs, 1981; Tufto et al., 1996; McLoughlin et al., 2000; Herfindal et al., 2005; reviewed in Adams, 2001).

In this study, food availability within a squirrel's home range was on average lower in the marginal mountain pine forest than in the Scots pine forest. Consequently, and in agreement with our first prediction of food-based differences in home range size, males and females in the marginal site used larger home ranges and core areas than in Scots pine forest. Moreover, the two sites also differed in temporal seed availability. In the Scots pine forest, conifer seeds were available for squirrels throughout most of the year, because some tree species (larch) had earlier seed maturation than others and cones of Norway spruce retain some of their seeds until the next spring. Consequently squirrels had access to (immature and/or mature) conifer seeds from mid June (immature larch seeds) to late April-May (seeds in partly open spruce cones; Wauters et al., 2005). In contrast, the mountain pine area is a monospecific forest where squirrels must deal with shortage of high-energy food resources during late spring-early summer, after complete dispersal of dwarf mountain pine seeds and before seed maturation of the current year's cone crop. The importance of seasonal food shortage in this marginal habitat was also supported by our observations of squirrels feeding on small, partly developed cones in July, while the first immature fresh but full sized seeds of $P$. mugo were extracted by early-mid August, 40-50 days later than immature larch seeds in the Scots pine forest. Hence, we believe that the shorter temporal availability of conifer seeds and the lower seed abundance in the mountain pine forest were the major determinants of habitat variation in space use, with red squirrels of both sexes using larger home ranges in the marginal than in the higher-quality habitat.

Individual variation in home range size was more strongly affected by variation in seed abundance in the marginal habitat, where range size increased with decreasing home range quality. In the Scots pine forest this relationship was not found. Since density of competitors and/or reproductive partners affects space use and social behavior in many territorial vertebrates (e.g. Erlinge et al., 1990; Fortier and Tamarin, 1998; Bond and Wolff, 1999; Revilla and Palomares, 2002; Kjellander et al., 2004), we expected that in the high-quality Scots pine forest home range or core area size would be more strongly affected by (intra-sexual) squirrel density (e.g. Wauters and Dhondt, 1992, 1998). However, this was not the case. Core area size of squirrels of either sex decreased with increasing density of animals of the same sex, but this relationship was most pronounced in the marginal habitat. Density only affected variation in core area and not home range size, suggesting that behavior related to intraspecific (and intra-sexual) competition is linked to areas of intensive, every-day use, a common pattern for 
Table 3

Patterns of core area overlap (\% overlap, mean \pm SD) of Eurasian red squirrels according to the sex by overlapping sex combination. Data by study site and by season within each study site. Sample size between brackets.

\begin{tabular}{|c|c|c|c|c|}
\hline Sex $\times$ overlapping sex & Male by males & Male by females & Female by males & Female by females \\
\hline CAN & (13) $12.5 \pm 16.1$ & (13) $22.7 \pm 25.7$ & (11) $71.7 \pm 55.1$ & (11) $5.0 \pm 7.9$ \\
\hline Spring-summer & (7) $23.0 \pm 15.4$ & (7) $21.4 \pm 19.1$ & (6) $96.3 \pm 60.3$ & (6) $3.0 \pm 5.2$ \\
\hline Autumn & (6) $0.1 \pm 0.2$ & (6) $24.1 \pm 33.8$ & (5) $42.2 \pm 32.6$ & (5) $7.3 \pm 10.5$ \\
\hline OGA & (15) $42.4 \pm 45.7$ & (15) $25.4 \pm 31.4$ & (13) $53.1 \pm 66.1$ & (13) $14.0 \pm 17.5$ \\
\hline Spring-summer & (10) $43.6 \pm 46.0$ & (10) $24.6 \pm 34.5$ & (7) $70.3 \pm 69.8$ & (7) $16.3 \pm 21.3$ \\
\hline Autumn & (5) $40.3 \pm 50.2$ & (5) $27.0 \pm 27.7$ & (6) $33.0 \pm 61.1$ & (6) $11.2 \pm 13.2$ \\
\hline
\end{tabular}

vertebrates in resource-limited habitats (McLoughlin et al., 2000; Steury and Murray, 2003; Kerr and Bull, 2006; Di Pierro et al., 2008).

In the marginal high-elevation mountain pine forest, weatherrelated energy constraints could become a limiting factor during winter, affecting squirrel space use, but our current data do not allow to explore these potential effects. Deep snow cover within the dense forest made it very difficult to access the study area in winter and to radio-track squirrels by homing-in, necessary to obtain reliable space use (exact locations) data. Hence, our space use monitoring was limited to spring-autumn when weather conditions were less harsh.

The Eurasian red squirrel is a solitary species with intra-sexual territoriality among adult females (Wauters and Dhondt, 1989, 1992) and a promiscuous mating system where older, dominant males increase their home ranges to overlap with more potential partners (Wauters et al., 1990; Lurz et al., 2005). Consequently, in most populations, males strongly overlap with females, while intrasexual overlap is low among females and higher (and proportional to density) among males (Wauters and Dhondt, 1992; Lurz et al., 2000; Wauters et al., 2001, 2005; Di Pierro et al., 2008). In this study we found a slightly different pattern: adult females showed intra-sexual territoriality in both sites, while intra-sexual overlap among males was typically high in spring-summer but strongly reduced in autumn in the marginal habitat (see Table 3 ). Moreover, in both sites females were overlapped more strongly by males in spring-summer than in autumn. In the mountain pine forest, higher female by males and male intra-sexual core area overlap in spring-summer was associated with males using larger home ranges and core areas in this season than in autumn, but this was not the case in the Scots pine forest (see Table 1). A possible explanation is that at low densities of adults (mountain pine forest, males $0.040-0.15 \mathrm{ha}^{-1}$, females $0.037-0.093 \mathrm{ha}^{-1}$ over 3 years, Rodrigues et al., 2010), males have to increase home ranges (and core areas) in spring-summer to meet potential partners, while at relatively high densities (Scots pine forest, males $0.18-0.31 \mathrm{ha}^{-1}$, females $0.16-0.27 \mathrm{ha}^{-1}$, over 6 years) males overlap with several females without having to enlarge their home ranges during the mating season.

Finally in our marginal population, intra-sexual territoriality remained high and stable across years. This is to some extent in contrast with a cost-benefit model proposed first by Carpenter and MacMillen (1976) and later by Maher and Lott (2000), according to which territorial behavior should occur only at intermediate levels of food availability, becoming disadvantageous outside upper and lower thresholds of food abundance. Several empirical studies have supported this model (e.g. Carpenter and MacMillen, 1976; KodricBrown and Brown, 1978; Hannon et al., 1987; Maher, 1994), and also in Eurasian red squirrels in mixed conifer forests the social system was disrupted after a Norway spruce seed-crop failure (Wauters et al., 2005). However, in the latter case, food availability was extremely low before squirrels strongly increased core areas and core area overlap, and we believe that in the three-year period we studied spacing patterns at the mountain pine forest, no situations of either extremely high or low seed-crop size occurred.

In conclusion, our study design did not allow us to determine the effects of distribution marginality on squirrel space use by itself. However, the low food abundance and low population densities, linked with extreme winter conditions (Rodrigues et al., 2010), in the marginal mountain pine forest affected space use, forcing squirrels, especially males, to maintain large home ranges. Squirrels responded more strongly to variation in food availability (inverse relation between home range size and $\mathrm{HRQ}$ ), and even to fluctuations in density (inverse relation between core area size and density of animals of the same sex), in the mountain pine than in the Scots pine forest, suggesting high behavioral plasticity to respond to the ecological constraints in this marginal habitat.

\section{Acknowledgements}

We thank Ambrogio Molinari, Stefania Martini, Veronica Mari, and Diana Rodrigues for their help with the fieldwork. Constructive comments by two anonymous referees greatly helped to improve the ms. This study is part of the ASPER (Alpine Squirrel Population Ecology Research) project, funded by the province of Sondrio (Servizio Agricoltura, Caccia e Pesca, Settore Risorse Ambientali) and the Stelvio National Park to Istituto Oikos NGO, Milan. Additional financial support was given by MIUR (Ministero dell'Istruzione, dell'Università della Ricerca, project COFIN 2003, number 2003053710-006) to Insubria University of Varese. Trapping and handling squirrels complied with the current laws on animal research in Italy and were carried out under permission of the Region of Lombardy. This is paper \#20 of the ASPER project.

\section{References}

Adams, E.S., 2001. Approaches to the study of territory size and shape. Annual Review of Ecology and Systematics 32, 277-303.

Badyaev, A.V., Ghalambor, C.K., 2001. Evolution of life histories along elevational gradients: trade off between parental care and fecundity. Ecology 82, 2948-2960.

Bond, M.L., Wolff, J.O., 1999. Does access to females or competition among males limit male home range size in a promiscuous rodent? Journal of Mammalogy $80,1243-1250$

Boutin, S., Wauters, L.A., McAdam, A.G., Humphries, M.M., Tosi, G., Dhondt, A.A., 2006. Anticipatory reproduction and population growth in seed predators. Science 314, 1928-1930.

Carpenter, F.L., MacMillen, R.E., 1976. Threshold model of feeding territoriality and test with a Hawaiian honeycreeper. Science 194, 639-642.

Case, T.J., Taper, M.L., 2000. Interspecific competition, environmental gradients, gene flow, and the coevolution of species' borders. The American Naturalist 155, 583-605.

Caudron, A.K., Joiris, C.R., Ruwet, J.-C., 2001. Comparative activity budget among grey seal (Halichoerus grypus) breeding colonies - the importance of marginal populations. Mammalia 65, 373-382.

Dias, P.C., 1996. Sources and sinks in population biology. Trends in Ecology \& Evolution 11, 326-330.

Di Pierro, E., Molinari, A., Tosi, G., Wauters, L.A., 2008. Exclusive core areas and intrasexual territoriality in Eurasian red squirrels (Sciurus vulgaris) revealed by incremental cluster polygon analysis. Ecological Research 23, 529-542. 
Erlinge, S., Hoogenboom, I., Agrell, J., Nelson, J., Sandell, M., 1990. Density-related home range size and overlap in adult field voles (Microtus agrestis) in southern Sweden. Journal of Mammalogy 71, 597-603.

Ferguson, S.H., McLoughlin, P.D., 2000. Effect of energy availability, seasonality and geographic range on brown bear life history. Ecography 23, 193-200.

Fortier, G.M., Tamarin, R.H., 1998. Movement of meadow voles in response to food and density manipulations: a test of the food-defense and pup-defense hypotheses. Journal of Mammalogy 79, 337-345.

García, J.T., Arroyo, B.E., 2001. Abiotic factors influencing reproduction in the centre and periphery of breeding ranges: a comparative analysis in sympatric harriers. Ecography 24, 393-402.

Garcia-Ramos, G., Kirkpatrick, M., 1997. Genetic models of adaptation and gene flow in peripheral populations. Evolution 51, 21-28.

Gonzalez-Megias, A., Gomez, J.M., Sanchez-Pinero, F., 2005. Regional dynamics of a patchily distributed herbivore along an altitudinal gradient. Ecological Entomology 30, 706-713.

Hannon, S.J., Mumme, R.L., Koenig, W.D., Spon, S., Pitelka, F.A., 1987. Poor acorn crop, dominance and decline in numbers of acorn woodpeckers. Journal of Animal Ecology 56, 197-207.

Hemson, G., Johnson, P., South, A., Kenward, R., Ripley, R., Macdonald, D., 2005. Are kernels the mustard? Data from global positioning system (GPS) collars suggests problems for kernel home range analyses with least-squares crossvalidation. Journal of Animal Ecology 74, 455-463.

Herfindal, I., Linnell, J.D.C., Odden, J., Nilsen, E.B., Andersen, R., 2005. Prey density, environmental productivity and home range size in the Eurasian lynx (Lynx lynx). Journal of Zoology 265, 63-71.

Hixon, M.A., 1980. Food production and competitor density as the determinants of feeding territory size. The American Naturalist 115, 510-530.

Kawecki, T.J., 2008. Adaptation to marginal habitats. Annual Review of Ecology, Evolution, and Systematics 39, 321-342.

Kenward, R.E. Hodder, K.H. Rose, R.J., Walls, C.A, Parish, T. Holm, J.L, Morris, P.A Walls, S.S., Doyle, F.I., 1998. Comparative demography of red squirrels (Sciurus vulgaris) and grey squirrels (Sciurus carolinensis) in deciduous and conifer woodland. Journal of Zoology 244, 7-21.

Kenward, R.E., South, A.B., Walls, S.S., 2003. Ranges 6 1.2: For the Analysis of Tracking and Location Data. Anatrack Ltd., Wareham, UK.

Kerr, G.D., Bull, C.M., 2006. Exclusive core areas in overlapping ranges of the sleepy lizard, Tiliqua rugosa. Behavioral Ecology 17, 380-391.

Kirkpatrick, M., Barton, N.H., 1997. Evolution of a species' range. The American Naturalist $150,1-23$

Kjellander, P., Hewison, A.J.M., Liberg, O., Angibault, J.-M., Bideau, E., Cargnelutti, B. 2004. Experimental evidence for density-dependence of home range size in roe deer (Capreolus capreolus L.): a comparison of two long-term studies. Oecologia 139, 478-485.

Kodric-Brown, A, Brown, J.H. 1978. Influence of economics, interspecific competition, and sexual dimorphism on territoriality of migrant rufous hummingbirds. Ecology 59, 285-296.

Lurz, P.W.W., Garson, P.J., Wauters, L.A., 2000. Effects of temporal and spatial variations in food supply on the space and habitat use of red squirrels, (Sciurus vulgaris L.). Journal of Zoology 251, 167-178.

Lurz, P.W.W., Gurnell, J., Magris, L., 2005. Sciurus vulgaris. In: Mammalian species, 769. American Society of Mammalogists.

Maher, C.R., 1994. Pronghorn male spatial organization: population differences in degree of non territoriality. Canadian Journal of Zoology 72, 455-464.

Maher, C.R., Lott, D.F., 2000. A review of ecological determinants of territoriality within vertebrate species. The American Midland Naturalist 143, 1-29.

Manier, M.K., Arnold, S.J., 2005. Population genetic analysis identifies source-sink dynamics for two sympatric garter snake species (Thamnophis elegans and Thamnophis sirtalis). Molecular Ecology 14, 3965-3976.

McLoughlin, P.D., Ferguson, S.H., Messier, F., 2000. Intraspecific variation in home range overlap with habitat quality: a comparison among brown bear populations. Evoutionary Ecology 14, 39-60.

Mehlman, P.T., 1989. Comparative density, demography, and ranging behavior of Barbary macaques (Macaca sylvanus) in marginal and prime conifer habitats. International Journal of Primatology 10, 269-292.

Millar, J.S., Innes, D.G., 1985. Breeding by Peromyscus maniculatus over an elevational gradient. Canadian Journal of Zoology 63, 124-129.

Parmesan, C., 2006. Ecological and evolutionary responses to recent climate change. Annual Review of Ecology, Evolution and Systematics 37, 637-669.

Revilla, E., Palomares, F., 2002. Spatial organization, group living and ecologica correlates in low-density populations of Eurasian badgers, Meles meles. Journal of Animal Ecology 71, 497-512.

Rodrigues, D., Wauters, L.A., Romeo, C., Mari, V., Preatoni, D., Mathias, Mda L. Tosi, G., Martinoli, A, 2010. Living on the edge: can Eurasian red squirrel (Sciurus vulgaris) persist in extreme high-elevation habitats? Arctic, Antarctic, and Alpine Research 42, 106-112.

Sagarin, R.D., Gaines, S.D., Gaylord, B., 2006. Moving beyond assumptions to understand abundance distributions across the ranges of species. Trends in Ecology \& Evolution 21, 524-530.
Salmaso, F., Molinari, A., Di Pierro, E., Ghisla, A., Martinoli, A., Preatoni, D. Cerabolini, B., Tosi, G., Bertolino, S., Wauters, L.A., 2009. Estimating and comparing food availability for tree-seed predators in typical pulsed-resource systems: alpine conifer forest. Plant Biosystems 143, 258-267.

Seaman, D.E., Powell, R.A., 1996. An evaluation of the accuracy of kernel density estimators for home range analysis. Ecology 77, 2075-2085.

Simon, C.A., 1975. The influence of food abundance on territory size in the iguanid lizard Sceloporus jarrovi. Ecology 56, 993-998.

Smith, A.T., 1974. The distribution and dispersal of pikas: influences of behavior and climate. Ecology 55, 1368-1376.

Sound, P., Veith, M., 2000. Weather effects on intra habitat movements of the western green lizard, Lacerta bilineata (Daudin, 1802), at its northern distribution range border: a radio-tracking study. Canadian Journal of Zoology 78 , $1831-1839$.

Spencer, A.W., Steinhoff, H.W., 1968. An explanation of geographic variation in litter size. Journal of Mammalogy 49, 281-286.

Steury, T.D., Murray, D.L., 2003. Causes and consequences of individual variation in territory size in the American red squirrel. Oikos 101, 147-156.

Sunde, P., Overskaug, K., Bolstad, J.P., Øien, I.J., 2001. Living at the limit: ecology and behaviour of tawny owls (Strix aluco) in a northern edge population in centra Norway. Ardea 89, 495-508.

Swihart, R.K., Slade, N.A., 1985. Influence of sampling interval on estimates of home range size. The Journal of Wildlife Management 49, 1019-1025.

Taitt, M.J., Krebs, C.J., 1981. The effect of extra food on small rodent population: II. Voles (Microtus townsendii). Journal of Animal Ecology 50, 125-137.

Thomas, C.D., Bodsworth, E.J., Wilson, R.J., Simmons, A.D., Davies, Z.G., Musche, M. Conradt, L., 2001. Ecological and evolutionary processes at expanding range margins. Nature 414, 577-581.

Tufto, J., Reidar, A., Linnell, J., 1996. Habitat use and ecological correlates of home range size in a small cervid: the roe deer. Journal of Animal Ecology 65, 715-724.

Verbeke, G., Molenberghs, G., 2000. Linear Mixed Models for Longitudinal Data. Springer Series in Statistics, Springer, New York.

Vucetich, J.A., Waite, T.A., 2003. Spatial patterns of demography and genetic processes across the species' range: null hypotheses for landscape conservation genetics. Conservation Genetics 4, 639-645.

Wauters, L.A., 2000. Squirrels - medium-sized granivores in woodland habitats. In: Halle, S., Stenseth, N.C. (Eds.), Activity Patterns in Small Mammals: A Comparative Ecological Approach. Springer, Berlin, pp. 131-143. Ecological Studies 141

Wauters, L.A., Bertolino, S., Adamo, M., Van Dongen, S., Tosi, G., 2005. Food shortage disrupts social organization: the case of red squirrels in conifer forests. Evolutionary Ecology 19, 375-404

Wauters, L.A., Dhondt, A.A., 1989. Body weight, longevity and reproductive success in red squirrels (Sciurus vulgaris). Journal of Animal Ecology 58, 637-651.

Wauters, L.A., Dhondt, A.A., 1992. Spacing behaviour of red squirrels, Sciurus vulgaris: variation between habitats and the sexes. Animal Behaviour 43, 297-311.

Wauters, L.A., Dhondt, A.A., 1995. Lifetime reproductive success and its correlates in female Eurasian red squirrels. Oikos 72, 402-410.

Wauters, L.A., Dhondt, A.A., 1998. Variation in spacing behavior of Eurasian red squirrels, Sciurus vulgaris in winter: effects of density and food abundance. In: Steele, M.A., Meritt, J.F., Zegers, D.A. (Eds.), Ecology and Evolutionary Biology of Tree Squirrels, pp. 71-77. Special Publication of the Virginia Museum of Natural History 6.

Wauters, L.A., Dhondt, A.A., De Vos, R., 1990. Factors affecting male mating success in red squirrels (Sciurus vulgaris). Ethology, Ecology \& Evolution 2, 195-204.

Wauters, L.A., Ghitiru, M., Bertolino, S., Molinari, A., Tosi, G., Lens, L., 2008 Demography of alpine red squirrel populations in relation to fluctuations in seed-crop size. Ecography 31, 104-114.

Wauters, L.A., Gurnell, J., Preatoni, D., Tosi, G., 2001. Effects of spatial variation in food availability on spacing behaviour and demography of Eurasian red squirrels. Ecography 24, 525-538.

Wauters, L.A., Lens, L., 1995. Effects of food availability and density on red squirrel (Sciurus vulgaris) reproduction. Ecology 76, 2460-2469.

Wauters, L.A., Matthysen, E., Adriaensen, F., Tosi, G., 2004. Within sex-density dependence and population dynamics of red squirrels Sciurus vulgaris. Journal of Animal Ecology 73, 11-25.

Wauters, L.A., Preatoni, D., Molinari, A., Tosi, G., 2007. Radio-tracking squirrels: performance of home range density and linkage estimators with small range and sample size. Ecological Modelling 202, 333-344.

Wiens, J.J., Graham, C.H., 2005. Niche conservatism: integrating evolution, ecology, and conservation biology. Annual Review of Ecology, Evolution, and Systematics 36, 519-539.

Zammuto, R.M., Millar, J.S., 1985. Life histories of ground squirrels over a climatic gradient. Ecology 66, 1784-1794.

Zong, C., Wauters, L.A., Van Dongen, S., Mari, V., Romeo, C., Martinoli, A., Preatoni, D., Tosi, G., 2010. Annual variation in predation and dispersal of Arolla pine (Pinus cembra L.) seeds by Eurasian red squirrels and other seed-eaters. Forest Ecology and Management 260, 587-594. 